\title{
VIDEO TO AMPLIFY BANKING STUDENT'S WRITING PERFORMANCE
}

\author{
Fenny Thresia
}

Muhammadiyah University of Metro

\begin{abstract}
Writing is activity to mix between the idea, vocabulary and also grammar. By looking at the problems, the teacher should make the proper method in teaching writing in order to increase the students writing skill and also make the writing be an interesting activity to them. One of the good methods is using video as a media of learning. Video can stimulates the student's to makes them easier to find the ideas in writing process, because video included 3D and also the complex media. This research was aimed at detecting the influence of using video as a media toward student's writing performance.This research was quantitative research form and the sampling technique was random sampling. The data collection method in this research used the documentation and test that consist of pre-test and pos-test. The data analysis technique of this research used T-test as the hypothetical statistic calculation. Based on the research analysis, there is any positive and significant influence of using video as a media toward students' writing performance of banking students.
\end{abstract}

Key words: Video, writing performance

\section{Introduction}

In the context of English language teaching in Indonesia, teaching and learning English is very important. English is the international language of the world. Learning English was a necessity in modern life. In the learning English, there are four basic skills such as listening, speaking, reading, and writing. The students should master the four of language skills so they can use English actively and effectively, especially in writing. Writing is the activity to present, demonstrate or describe a language in the contextual medium by using a set of signs or symbols. The importance of writing in daily life or also in our social life, like in education and business aspect.

Although writing is very important skill but it is also one of the most difficult skill for non native student. Because writing is an activity to mix between the idea, vocabulary and also grammar. The writing skills are more complex and sometimes difficult to be taught, requiring mastery not only grammatical and therotical devices but also conceptual and judgemental elements.

There are another factor that makes writing be the most difficult subject. The other reason, there are many kinds of texts in English, such as narrative, descriptive, ect. And each text has different characteristics 
especially in descriptive text. Because in this text, the students must describe a particular person, place, or thing. Even, there are the teachers who asked their students to practice the writing desriptive text, but they do not yet use the proper media or the interesting media in the learning process. Therefore, the students only depend on their imagination in describing the object, of course it is not enough to get the idea of the descriptions.

By looking at the problems, therefore the lecturer should find a proper method in teaching writing in order to increase the students writing skill and also change the students perception that writing is very difficult. Moreover, it will make writing be an interesting activity to them. One of the good method to teach the writing descriptive text is using video as a media of learning. Video help students to get ideas in writing, because video included 3D (three dimensional) media and also the complex media. Video shows an object from all directions and it has the ability to display an image element, sound, accompanied by a motion (moving images) simultaneously. By watching the video, the students are expected to get positive things and then they try to write it.

The writer found the several factors that have affected, but the main factor is the student's have the difficulties to find the idea in the writing process, it's because the application of a less appropriate method the the learning process. Based on situation above, the writer conductted a research entitled.
Siahaan (2008:2)Writing is a skill to communicate the information to the reader or group of reader. In writing, the skill is also realized by the ability to apply the rules of the language and to transfer the information from our mind to the reader effectively. Petty and Jansen ( 1998:363) statement that writing is the mental and phisical act to forming letters and words. But it is more than that. It is putting words into sentences, sentences into paragraph, spelling words correctly, punctuating and capitalizing in customery ways, and observing conventions in written forms and more.

\section{McCrimmon}

Description is the strategy to present a verbal portrait of person, place, or thing. It can be used as a technique to enrich other forms of writing or as a dominant strategy for developing a picture of "what it looks like".

Etymologically, video derived from the Latin language "videre", and the meaning is "I see". Video can describe the moving objects accompanied by natural sounds or sounds appropriate.Arsyad (49)video can provide the information, describe the process, explain the complex concepts, teaching the skills, abbreviate or extend the time, and affect the attitudes. Video can conveys the facts (events / important events, news) and fictitious (such as story), informative, educational and instructional, Sadiman (74)

Video is not only entertaining but also aducating the people. In 
teaching and learning process, video serve the conceptual subject and the conceptual object by providing the interesting subject such as motion, magnification, sound, colour, the presentation of fact, etc. Video has many types, various types of video was made with the variety of purposes. There are using video for broadcast, teaching/education, or just for entertain. In terms of capacity, quality and ease of operation, it will also vary according to the usage.

Arsyad (49) Video has the advantages that became a view when use it as the instructional media in the learning process, they are :

a) Video complete the student's basic experiences when they are read, discuss, practice, and others.

b) Video shows the object that normally can not be seen, such as the workings of the heart when it beats.

c) Video can save the time and describe a process that can be watched perpetually and directly, for example: the steps and the correct way to perform ablution.

d) Video can present the dangerous moment when viewed directly, such as lava mountain or wild animal behavior.

e) Video that containing the positive values can bring the ideas and discussion within the group of students.

f) In the presentation, the video does not require a dark room, it is contrast to a movie.

g) By using video, the viewer or the audien can get some information from the experts / specialists, without have to wreaking the experts directly.

Arsyad (50)And there are several thing that must considered when we use the video in the learning process, include :

a) Using the video in the learning process was very expensive, because we require the expensive equipment and complex.

b) When the video was shown, the images moving continuously, so not all students are able to follow the information that conveyed the video.

c) Videos available does not always correspond to the needs and desired learning objectives, unless the video was designed and manufactured specifically for their own need.

\section{Teaching Writing Using Video}

Video is one of the media that assist the teachers in teaching and learning writing process. In addition, video can help the students to improve their knowledge of vocabulary, fluency, grammar. Sometimes, by using video in teaching learning process can avoid the students' boredom. Video is the interesting media, because it shows the picture, animation and live action. This characteristic can support the effectiveness of teaching writing, actually in the descriptive text, because in making descriptive text, the student's need a clear things to describe. 
Based on the statements above, the writer used some sequence of the implementation of using video to teaching writing in the class, they are :

1) The writer selected a certain topic. And the teacher prepared the audio visual aids. In this case, the writer choosed the video as a media in the learning process.

2) The writer told what they are going to learn (in this case the, writer choose the descriptive text).

3) The writer started the research activity (teaching descriptive text). First, the teacher turn on the video by using LCD projector. Second, the writer mention and explained the point of video and then wrote the sentences that has mentioned on the whiteboard.

4) The writer repeated the leaning process in the several times.

5) The writer held the question and answer session with the student's in the several times, if there are students didn't understand yet about the materials.

6) The writer asked the students to do the test based on the material to know the students acquisition result.

\section{METHOD}

In this research, the writer used the quantitative research as the experimental method. Cresswell (2002:15) quantitative research is a research method which is based on the philosophy of positivism, it used to study about the population or sample, and which is the data were collected using the research instruments and data analysis based on statistics. The population in this research is the bangking students at University Muhammadiyah of Metro that consist of 22 students. Therefore the writer took all population become the subject of study.

There are two variables in this study; independent and dependent variable. Sugiyono (2008:56) independent variable is a variable that is not influenced by another variable. Independent variable is the major variable which is hoped to investigate. The independent variable (X) of this research is the influence of using of video as a media at the first semester banking students. Video media is an audio-visual media used in the writing learning process, where is video expected to attract the student's attention, help to finding the ideas, or new vocabulary, so that can improve the students' writing performance. Therefore the indicator of using video media as the independent variable as bellow: the students more interest in the learning English writing, the students more active in the process of learning, and the students easier to find out the ideas in the writing process.

The dependent variable is a variable influenced by independent variable. Dependent variable is the variable which was observed and measured to determine the effect of the independent variable, Sugiyono (2008:56). The dependent variable (Y) of this research is student's writing performance. Writing is one of the main dimensions of communication. It is include one of four main skills that are required in EFL teaching. But, is 
more complex and difficult than the other skills. Therefore the indicator of students' writing performance as the dependent variable as bellow: the students are able to identify the information of the writing text, the students' able to know the language features of writing descriptive text, the students are able to identify the general structure of the writing text. This study use test to measure the students' ability.

Test is an examination of someone's knowledge or ability, consisting of questions for them to be answered or to performed the activities based on the command of the test, Oxford (2010). The writer used the test as data collection method to measure both of the variables. Furthermore, the writer used test to collect the data that consist of pre-test and post-test as data collection method to measure of the students' writing paragraph performance.

Arikunto(2010:126) defined the instrument as the tool of research which is used in each method. Furthermore, the research instruments conclude: Instrument in this research is designed and adjusted with the indicators which have been specified. Moreover, the instrument that used in this research is writing test about the descriptive text form. Instrument calibration is a scale of measurement that used to describe the instrument standard that will be used". The test was used in this research is writing test which consist of the descriptive paragraph. The biggest score of writing descriptive text is 100 and the lowest score of item is 0 .

Table 1

Grilles Instrument

\begin{tabular}{|l|l|l|c|}
\hline NO & Variables & \multicolumn{1}{|c|}{ Indicators } & Items \\
\hline 1. & $\begin{array}{l}\text { Independent } \\
\text { Variable (X) } \\
\text { Video as a media }\end{array}$ & $\begin{array}{l}\text { The students more interest in the } \\
\text { learning English writing. } \\
\text { The students more active in the } \\
\text { process of learning. } \\
\text { The students easier to find out } \\
\text { the ideas in the writing process. }\end{array}$ & Composing \\
\hline 2. & $\begin{array}{l}\text { Dependent } \\
\text { Variables (Y) } \\
\text { Students' Writing } \\
\text { Performance }\end{array}$ & $\begin{array}{l}\text { The students are able to identify } \\
\text { the information of the writing } \\
\text { text. } \\
\text { The students' able to know the } \\
\text { language features of writing } \\
\text { descriptive text. } \\
\text { The students are able to identify } \\
\text { the general structure of the } \\
\text { writing text. }\end{array}$ & \\
\hline
\end{tabular}


The activities after data have collected is called data analysis. The activities include grouping the data based on variables and respondens. To investigate whether there is any positive and Influence of using video as a media toward students' writing performance at the first semester

\section{RESULT}

The writer conducted pre-test in the first meeting of research in order to find out the initial differences between the groups who have similar level and characters. The pretest was used in this research is essay tests form. The test was followed by 32 students. The highest score is 75 and the lowest score was 40 . banking students, so the writer analyzes the data by using $T$-test. The data obtained from pre-test and posttest were analysed by using matched $T$-test to know whether watching video gives the significant influence or not to increase the students' writing performance.

\section{Chart 1}

\section{Histogram of the Student's Post-test Score}

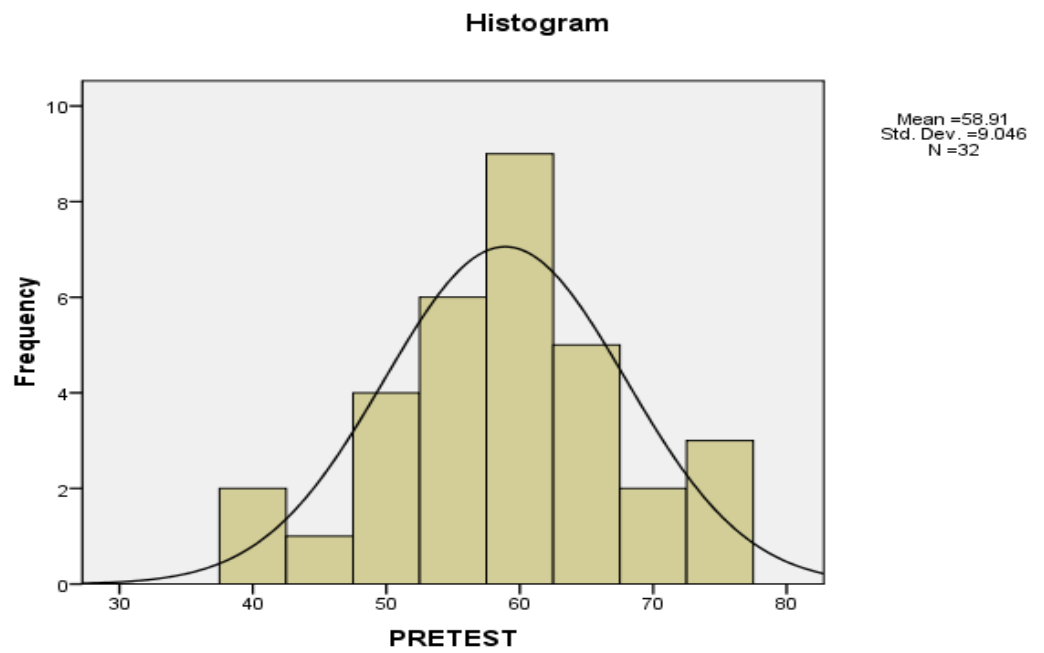


Based on the cahart above, it can be inferred that $87 \%$ or 28 of students reached of the Minimum Mastery Criteria. Therefore, it can be inferred that the student's writing performance in the post-test was improved by implementation of video in teaching writing process.

\title{
Hypotheses Testing
}

\begin{abstract}
After administering the written test method, the writer analyzed the data by using of T-test with two variables in order to prove whether any positive and significant influence of using video as a media toward students' writing performance at the first semester of banking students, as follow:
\end{abstract}

The writer analysed the research data by using T-test technique in the SPSS 16 program, as bellow:

Table 2

Paired Samples Statistics of the Test

Paired Samples Statistics

\begin{tabular}{|r|r|r|r|r|}
\hline & Mean & $\mathrm{N}$ & \multicolumn{1}{c|}{$\begin{array}{c}\text { Std. } \\
\text { Deviation }\end{array}$} & \multicolumn{1}{|c|}{$\begin{array}{c}\text { Std. Error } \\
\text { Mean }\end{array}$} \\
\hline Pair 1 POSTTES \\
$\begin{array}{l}\mathrm{T} \\
\text { PRETEST }\end{array}$ & 58.91 & 32 & 6.810 & 1.204 \\
\hline
\end{tabular}

32 students and the standard

The table above showed that mean of pre-test result was 74.38. The standard deviation was 6.810 with total sample of

error mean was 1.204. Furthermore, the mean of posttest result was 58,91, the standard deviation was 9.046 with total sample of 32 students and the standard error mean was 1.599 .

Table 11 
Paired Sample Correlation of Test

Paired Samples Correlations

\begin{tabular}{|ll|r|r|r|}
\hline & $\mathrm{N}$ & Correlation & Sig. \\
\hline Pair 1 & $\begin{array}{l}\text { POSTTEST \& } \\
\text { PRETEST }\end{array}$ & 32 & .840 & .000 \\
\hline
\end{tabular}

The table above showed that correlations between pre-test and posttest were .840 with significance .000 . So, it is concluded that there was any correlation between pre-test and post-test result.

Table 12

Paired Samples of Test

\begin{tabular}{|c|c|c|c|c|c|c|c|c|}
\hline & \multicolumn{5}{|c|}{ Paired Differences } & \multirow[b]{3}{*}{$\mathrm{T}$} & \multirow[b]{3}{*}{ df } & \multirow{3}{*}{$\begin{array}{l}\text { Sig. } \\
(2- \\
\text { tailed })\end{array}$} \\
\hline & \multirow[b]{2}{*}{ Mean } & \multirow{2}{*}{$\begin{array}{c}\text { Std. } \\
\text { Deviatio } \\
\mathrm{n}\end{array}$} & \multirow{2}{*}{$\begin{array}{c}\text { Std. } \\
\text { Error } \\
\text { Mea } \\
\mathrm{n}\end{array}$} & \multicolumn{2}{|c|}{$\begin{array}{l}95 \% \text { Confidence } \\
\text { Interval of the } \\
\text { Difference }\end{array}$} & & & \\
\hline & & & & Lower & Upper & & & \\
\hline $\begin{array}{ll}\text { Pai } & \text { Posttest } \\
\text { r } 1 & \text {-Pretest }\end{array}$ & $\begin{array}{c}15.46 \\
9\end{array}$ & 4.977 & .880 & 13.674 & 17.263 & $\begin{array}{c}17.58 \\
1\end{array}$ & $\begin{array}{l}3 \\
1\end{array}$ & .000 \\
\hline
\end{tabular}

The table above illustrated that the mean of pretest and post test result was 15.469 and the standard deviation was 4.977 with the standard error mean was $.880 . t_{\text {observed }}$ Was 17.581 with the degree of freedom was 31 to confidence interval of the difference $95 \%$. 
After considered the t-test table by using $d f 31$, the writer didn't find it

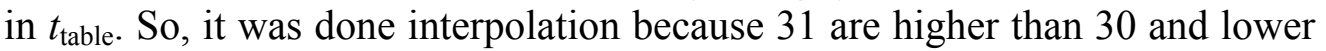
than 40 . It can be found as follows:

Table 13

Critical Value of $t_{\text {-table }}$

\begin{tabular}{|c|c|c|}
\hline Table Significance & $5 \%$ & $1 \%$ \\
\hline$d f 30$ & 2.042 & 2.750 \\
\hline$d f 40$ & 2.021 & 2.704 \\
\hline
\end{tabular}

Table 14

Interpolation of $t_{\text {-table }}$

\begin{tabular}{|c|c|c|}
\hline Interpolation & $5 \%$ & $1 \%$ \\
\hline$d f 30+d f 40 / 2$ & $2.042+2.021 / 2$ & $2.750+2.704 / 2$ \\
\cline { 2 - 3 } & 2.031 & 2.727 \\
\hline
\end{tabular}

From the data analysis above, it can be known that:

$\begin{array}{ll}t_{\text {observed }} & =17.581 \\ t_{\text {table }} & =2.031(5 \%) \text { and } 2.727(1 \%)\end{array}$

Finally, the data confirmed that $t_{\text {observed }}(17.581)$ is higher than $t_{\text {table }}$ (2.031 in 5\% and 2.727 in 1\%). Therefore, it was concluded that Ha was accepted and Ho was rejected. It means that there is a positive and significant influence of using video as media in toward student's writing performance at the eighth graders Junior High School 5 Metro in academic year 2013/2014. 


\section{CONCLUSION AND SUGGESTION}

\begin{abstract}
Based on analysis from the research result above, the writer concluded that using video as the instructional media has the positive and significant influence toward students' writing performance. Moreover, the positive and significant influence was clarified by the assumption of the critical value of between the result of pre-test and posttest of students' writing performance.
\end{abstract}

There are some suggestion based on the research; for the students are suggested to enrich their vocabulary to make them easier in the writing process. They students should

\section{BIBLIOGRAPHY}

Arikunto, S. (2010). Prosedur Penelitian Suatu Pendekatan Praktik, Jakarta: Rineka Cipta.

Arsyad, A. (2011). Media Pembelajaran, Jakarta: Raja Grafindo Persada.

Crewell, W. J. (2008). Educational

Research: Planning,

Conducting, and Evaluating

Quantitaive and Qualitative

Research. Upper Saddle River, be more active in learning English, if they do not understand about the lesson that delivered by their teacher, they should ask to the teacher. For the English teacher are suggested to give extrinsic motivation to make their students more enthusiasm in the learning process. They should use the suitable strategies and interesting technique to make the students more active in the English learning process. It is suggested for the other researchers for further to be able develop this research with the new innovations and hopefully the results of this research become the reference for other researcher.

\section{NJ: Pearson Merril Prentice}

Hall

Crimmon, J. (1983). Writing With The Purpose, United States of America: Hougton Miffin.

Sadiman, A.2003. Media Pendidikan. Jakarta: Raja Grafindo Persada.

Sugiyono. (2008). Metode Penelitian Kuantitatif Kualitatif Dan $R \& D$, Bandung: Alfabeta.

Petty, T \& Walter. 1998. Developing Children Language. Allyn Bacan 